\title{
Influence of Sustainable Logistics on Operational Performance of Timber Processing Firms in Nakuru County
}

\section{Caroline Mundia}

Department of Accounting, Finance and Management Science, Egerton University, Nakuru, Kenya

\section{Email address:}

muthcarol@gmail.com

\section{To cite this article:}

Caroline Mundia. Influence of Sustainable Logistics on Operational Performance of Timber Processing Firms in Nakuru County. International Journal of Economics, Finance and Management Sciences. Vol. 4, No. 5, 2016, pp. 257-262. doi: 10.11648/j.ijefm.20160405.14

Received: August 21, 2016; Accepted: September 2, 2016; Published: September 22, 2016

\begin{abstract}
This study was informed by the literature gap on the relationship between sustainable logistics and operational performance, especially among processing firms in Kenya. It aimed at establishing the influence of sustainable logistics on operational performance of timber processing firms in Nakuru County. Data for the study was collected from Comply Company. This was a cross sectional survey where data was collected at single point in time for the purpose of the study. The study involved employees in procurement, finance and marketing departments of Comply Company as respondents. Data for the study were collected by aid of structured questionnaires that were checked for validity and reliability before actual data collection. Collected data were coded, cleared and analysis through statistical packages for social sciences (SPSS). Regression analysis with one tailed t-test ware used to establish the relationship between Sustainable Inbound Logistics, Sustainable Outbound Logistics and Operational Performance. The findings revealed that there is significant positive influence of Sustainable Inbound Logistics and Sustainable Outbound Logistics on Operational Performance. The study recommends that manufacturing and processing organizations should consider sustainable logistics activities in their operations if they are to achieve improved operational performance. The study further suggests that study be conducted to explore on sustainable logistics activities that would be used to achieve operations improvement in service industry.
\end{abstract}

Keywords: Sustainable Inbound Logistics, Sustainable Outbound Logistics, Operational Performance

\section{Introduction}

Sustainability is gaining popularity in literally all aspects of business. In supply chain and logistics, sustainable logistics has emerged as one of the strategies of enhancing sustainability in supply chain operations. Kafa et al (2013) conceptualised sustainable logistics through the triple logistics management; economic, social and environmental. Economic sustainability is generally concerned with reduced cost and increased profitability (Green et al., 2012). It is focused on elimination or reductions of costs related to the environment like cost of acquiring materials and energy.

According to Ninlawan et al. (2010), an economically performing organization is an organization that is able to achieve decreased cost for materials purchasing, decreased cost for energy consumption, decreased costs for waste treatment, decreased cost for waste discharge and decreased costs associated with environmental accidents in their operations. Laosirihongthong et al. (2013) associated improved economic performance with improved operations, what Green et al. (2012) called operational performance. He appreciates that improved operations leads to increase in the amount of goods delivered on time, decrease in inventory levels, decrease in scrap rate, increase in product quality, increase in product line, improved capacity utilization.

Social sustainability is the intangible parameters that are concerned with the image the organization and its products have to its customers and its stakeholders (Laosirihongthong et al., 2013). An organization performing socially enjoys improved community relations and corporation image (Chien, 2007). One of the main reasons why organizations adopt sustainable strategies is to enhance internal operations. This study intends to determine the influence of sustainable logistics on operational performance of timber processing firms in Nakuru County.

\subsection{Objectives of the Study}

i. To determine the influence of sustainable inbound 
logistics on operational performance of timber processing firms in Nakuru County.

ii. To determine the influence of sustainable outbound logistics on operational performance of timber processing firms in Nakuru County.

\subsection{Hypotheses of the Study}

$\mathrm{HO}_{1}$ : sustainable inbound logistics does not have significant effect on operational performance of timber processing firms in Nakuru County.

$\mathrm{HO}_{2}$ : sustainable outbound logistics does not have significant effect on operational performance of timber processing firms in Nakuru County.

\section{Literature Review}

\subsection{Sustainable Logistics}

Kafa et al (2013) developed key parameters for sustainable development (SD) under economic, environmental and social perspectives. This was with the aim of evaluating economic, environmental and social performance so as to achieve the benefits of green supply chain management. This study adopted the parameters in developing and understanding of sustainable logistics.

Table 1. Sustainability Performance Measures for Sustainable Logistics.

\begin{tabular}{|c|c|c|}
\hline SD Perspective & Measure & Metric \\
\hline \multirow{5}{*}{$\begin{array}{l}\text { Economic } \\
\text { perspective }\end{array}$} & $\begin{array}{l}\text { Environmental } \\
\text { cost }\end{array}$ & $\begin{array}{l}\text { Costs of environmental } \\
\text { compliance, recycling, energy, } \\
\text { disposal etc }\end{array}$ \\
\hline & Supply chain cost & $\begin{array}{l}\text { Delivery, inventory and } \\
\text { information sharing costs }\end{array}$ \\
\hline & Quality & $\begin{array}{l}\text { Customer complaints level, } \\
\text { availability of green product } \\
\text { warranty, scrap, rework etc }\end{array}$ \\
\hline & Flexibility & $\begin{array}{l}\text { Demand, delivery and } \\
\text { production flexibility }\end{array}$ \\
\hline & Responsiveness & $\begin{array}{l}\text { Manufacturing, purchasing, on } \\
\text { time delivery and product return } \\
\text { lead-time }\end{array}$ \\
\hline \multirow{4}{*}{$\begin{array}{l}\text { Environmental } \\
\text { perspective }\end{array}$} & $\begin{array}{l}\text { Level of process } \\
\text { management }\end{array}$ & $\begin{array}{l}\text { Levels of process optimization, } \\
\text { pollution control, energy } \\
\text { consumption etc }\end{array}$ \\
\hline & Product Features & $\begin{array}{l}\text { Level of recycled material used, } \\
\text { availability of eco-labeling, } \\
\text { usage of design-for-assembly etc }\end{array}$ \\
\hline & $\begin{array}{l}\text { Recycling } \\
\text { efficiency }\end{array}$ & $\begin{array}{l}\text { Recycling time, energy } \\
\text { consumption during recycling } \\
\text { and waste reduction }\end{array}$ \\
\hline & $\begin{array}{l}\text { Environmental } \\
\text { technology }\end{array}$ & $\begin{array}{l}\text { Level of clean technologies and } \\
\text { number of new products and } \\
\text { process }\end{array}$ \\
\hline \multirow{3}{*}{$\begin{array}{l}\text { Social } \\
\text { perspective }\end{array}$} & $\begin{array}{l}\text { Management } \\
\text { commitment }\end{array}$ & $\begin{array}{l}\text { Employees motivation, } \\
\text { environmental control and } \\
\text { management initiatives etc }\end{array}$ \\
\hline & $\begin{array}{l}\text { Customer } \\
\text { satisfaction }\end{array}$ & $\begin{array}{l}\text { Customer interest and } \\
\text { satisfaction from green products }\end{array}$ \\
\hline & $\begin{array}{l}\text { Employee } \\
\text { development }\end{array}$ & $\begin{array}{l}\text { Employee training on green } \\
\text { operations }\end{array}$ \\
\hline
\end{tabular}

Source: Kafa et al. 2013

\subsection{Sustainable In-bound Logistics}

In-bound logistics can be defined as materials management system that is concerned with purchasing and supplier management. It is the aim of every production firm to reduce the necessary overhead and resource consumption needed to manage inventory (Chandrakar \& Kumar, 2012). The approach adopted has been to reduce inventory, thus reducing or eliminating costs associated with inventory like storage costs and waste (Toke et al. 2010). Some producers have opted to deliver inputs and produce in small batches. Just in Time (JIT) method of manufacturing system has been seen as one way that can be used to reduce inventory costs and at the while at the same time meeting customer orders.

JIT is defined by Lee White as an inventory control philosophy whose goal is to maintain just enough materials in just the right place at just the right time to make just the right amount of products. JIT manufacturing system requires that all materials arrive where they are needed, when they are needed and in the exact quantity needed. These materials must be made available in their usable form. The manufacturing firm must make timely and proper materials forecasts and communicate this to suppliers. It is important to note that JIT environment permits only few suppliers making it extremely important to build strong and long term relationship with the suppliers as well as well-developed supply chain system (Nimawat \& Namdev, 2012).

According to Nimawat and Namdev (2012), reverse logistics is an aspect of sustainable inbound logistics and refers to the role of logistics in product returns, source reduction, recycling, materials substitution, reuse of materials, waste disposal, repair and remanufacturing. It is a system for the recovery of used materials and products. Organizations can implement reverse logistics through recycling and waste logistics which can be established according to the actual need for the collection, classification, processing, packaging, handling, storage, and distribution to specialized treatment facility for processing (Zhang and Zheng, 2010). According to Olaf Schatteman (2013), reverse logistics involves the activities to avoid returns, to reduce materials in the forward system so as to reduce materials flow back and ensure reuse and recycling of materials.

Reverse logistics is associated with a number of benefits: such benefits include increased revenues from secondary sales, introduction of new products in place of unsold and slow moving stock, improved shareholder goodwill and public perception, reduced operating costs from reuse of recovered products and components and higher turnover rate due to better management of returns inventory (Nylund, 2012). The process of reverse logistic can be explained in terms of: removing new or used products from their initial point in a supply chain and redistributing the products using disposition management rules that will result in maximized value at the end product.

A good reverse logistics process should have the following characteristics: Firstly, it must establish convenient collection location to facilitate reception of recovered goods. Secondly, 
there must be in place a packaging and storage systems to ensure the remaining value in the recovered good is not lost due to poor handling. Thirdly, there must in place a transportation mode compatible with existing forward logistic system to facilitate movement. Lastly, there must be in place a well-managed process to either return the goods to storage warehouses, return goods to the original manufacturer, selling goods in secondary markets, recycling, to get maximum value realization (Wipro, 2009).

\subsection{Sustainable Outbound Logistics}

\subsubsection{Sustainable Distribution}

Manufactured products have to reach the market in time; the market has to be informed about the products' availability, their features and capabilities. This requires appropriate distribution and marketing systems. It is important that environmental concerns are taken care of by offering environmentally friendly products through environmentally friendly distribution and marketing system. Green distribution is achievable through; green packaging, green transportation and logistics (Nimawat \& Namdev, 2012).

It is important that the products are packed in a way that minimizes negative impacts on the environment. According to Ninlawan et al., (2010 Green packaging involves downsized packaging and use of green packaging materials. They also point out the need to cooperate with vendors to standardize packaging, encourage and adopt returnable packaging methods, promote recycling and reuse of packaging materials. On the other hand, Zhang and Zheng (2010) pointed out that green packaging can be achieved by use of biologically gradable plastics and implementation of simplified packaging as this can significantly reduce negative environmental impacts as well as reduce packaging waste.

Use of packaging materials that can be recovered or regenerated not only helps to reduce their impact on the environment, but also encourages use of recycled materials and to reduce waste disposal costs. Al-Odeh and Smallwood (2012) pointed out sustainable design strategies for the product and for the package as the first activities of implementing green supply chain management.

The next aspect of green distribution is green storage. It is the aim of every business organization to reduce transport mileage and save transportation costs as much as possible. There is therefore the need to choose the best location for the storage facility and come up with the most appropriate storage layout with adequate space. Too dense storage facility layout will lead to increased number of transport trips resulting to increased energy consumption and emissions of pollutants to the environment. Too lose facility layout on the other hand will reduce the efficiency of transport and increase load rate. The storage facility should be capable of storing different categories of materials. In addition, the design and construction of storage facilities must meet the requirements of non-polluted environment, while strengthening maintenance of good humidity, corrosion, waterproofing among other factors (Zhang \& Zheng, 2010)

Another important dimension of green distribution is green transportation and logistics. According to Zhang and Zheng (2010), one of the business activities with greatest impact on the environment is the means of transport, especially through emissions, noise and traffic congestion caused by road transport. Joint distribution and uniform delivery of materials can improve resource allocation, reduce the flow of materials, improve effectively and ease traffic congestion conditions especially on roads. Firms can use third party logistics to improve use and allocation of resources and avoid issues such uneconomical transport operations, overdependence on own transport systems and increased pollution. Firms can also deliver directly to user site. Products can be transported together rather than in small batches using alternative fuel modes so as to reduce the number of trips and hence reduce emission (Ninlawan et al., 2010). To Al-Odeh \& Smallwood (2012), factors like fuel, modes of transport, infrastructure, and operational practices are important factors to consider in developing green transportation.

Toke et al. (2012) discussed some tradeoffs facing logistics. While waiting for freight to become a full load may lead to longer lead times, it is sometimes associated with cost savings and reduction of emission to the environment. Selection of transportation mode is another factor. Different transport modes utilize different levels of energy and vary in efficiency. Others are also considered to be more flexible than others. Timing, speed and flexibility are therefore very important factors to consider in choosing a transportation option. Another important tradeoff is the 'carrier', the choice for career will depend on factors such as the nature of the products, whether they require special conditions, whether they have uniform shape, their size etc.

However, if analysis is done on the basic characteristics of logistical systems, a number of inconsistencies with regards to environmental compatibility become evident. Rodrigue et al. (2001) discussed basic paradoxes of sustainable logistics as summarized in the table 2 .

Table 2. Paradoxes of Sustainable Logistics.

\begin{tabular}{|c|c|c|}
\hline Dimension & Outcome & Paradox \\
\hline Costs & $\begin{array}{l}\text { Costs reduction through } \\
\text { improved packaging and } \\
\text { reduced wastes with most } \\
\text { of the benefits to the } \\
\text { distributors. }\end{array}$ & $\begin{array}{l}\text { Environmental costs are often } \\
\text { externalized. }\end{array}$ \\
\hline $\begin{array}{l}\text { Time/ } \\
\text { Flexibility }\end{array}$ & $\begin{array}{l}\text { Flexible and efficient } \\
\text { distribution achieved } \\
\text { through Integrated supply } \\
\text { chains. }\end{array}$ & $\begin{array}{l}\text { More space and energy } \\
\text { consumption and hence more } \\
\text { emission due to extended } \\
\text { production, distribution and } \\
\text { retailing structures. }\end{array}$ \\
\hline Network & $\begin{array}{l}\text { Improved efficiency of } \\
\text { the distribution system } \\
\text { through network changes. }\end{array}$ & $\begin{array}{l}\text { Concentration of adverse } \\
\text { environmental impacts next } \\
\text { to major hubs and along } \\
\text { corridors and Pressure on } \\
\text { local communities. }\end{array}$ \\
\hline Reliability & $\begin{array}{l}\text { Reliable and timely } \\
\text { distribution of materials } \\
\text { and people }\end{array}$ & $\begin{array}{l}\text { Transportation modes used } \\
\text { are the least environmentally } \\
\text { efficient. }\end{array}$ \\
\hline Warehousing & $\begin{array}{l}\text { Reduction of the needs } \\
\text { for private warehousing } \\
\text { facilities. }\end{array}$ & $\begin{array}{l}\text { Inventory contributing to } \\
\text { congestion and space } \\
\text { consumption. }\end{array}$ \\
\hline
\end{tabular}




\begin{tabular}{lll}
\hline Dimension & Outcome & Paradox \\
\hline \multirow{3}{*}{ E-commerce } & Better business & Adoption of physical \\
& $\begin{array}{l}\text { opportunities and } \\
\text { diversification of the } \\
\text { supply chain systems. }\end{array}$ & $\begin{array}{l}\text { distribution systems with } \\
\text { higher levels of energy } \\
\text { consumption. }\end{array}$ \\
\hline
\end{tabular}

Source: Rodrigue et al., (2001)

\subsubsection{Sustainable Marketing}

There has been increased customer information exposure in the recent years. This has led to global increase in concern and pressure on organizations to protect consumer rights, and ensure their operations and products are in accordance with customer rights and have no adverse effects on the environment. Al-Odeh and Smallwood, (2012) pointed out that achieving sustainable marketing needs keeping biological balance and pay more attention to environmental protection. The concept of green marketing tries to address these issues. It involves commitment of organizations to make sure their products and operations are environmentally friendly. According to Nimawat and Namdev (2012), sustainable marketing is any marketing activity of an organization that aims at creating a positive effect or removes a negative effect of a particular product on the environment. In their study on green supply chain management in India, they discuss a number of benefits associated with green marketing. Such benefits include owners' satisfaction, organization social acceptance and improved sustainability. It also brings an organization close to its clients, particularly clients with particular interest consumer rights and environment. In addition to the above benefits, Al-Odeh and Smallwood (2012) argued that sustainable marketing helps organizations enhance their relationship with customers, suppliers, and other stakeholders.

\subsection{Operational Performance}

As pointed by Pierre et al. (2012) organizational performance comprises three specific areas: financial performance, market performance and operational performance. To Rha (2010), operational performance is the ability of an organization to achieve high efficiency, high level of customer service and ability to respond to changing business environment. Teuteberg and Wittstruck (2010) on the other hand identified three dimensions of organizational performance. These are environmental performance, economic performance and social performance.

According to Ninlawan et al. (2010), operational performance is about the organization being in a position to achieve decreased cost for materials purchasing, decreased cost for energy consumption, decreased costs for waste treatment, decreased cost for waste discharge and decreased costs associated with environmental accidents in their operations. Operational performance is one of the most important aspects of sustainable procurement. It is also based on interaction of manufacturing, logistics, and material, distribution and transportation functions within an organization (Muma et al., 2014).

According to Zhu et al. (2007) cooperation with suppliers and other members of supply chain helps to achieve environmental performance. Sustainable and eco-friendly designs need manufacturers to design products that minimize consumption of materials and energy, facilitate re-use, and recycle and recovery of component materials and parts and reduce use of hazardous products within manufacturing process.

According to Osuga et al. (2015), Purchasing as a function may help in achievement of operational performance by ensuring that purchasing done in time and from right sources. Purchasing forms the biggest part of inbound logistics. Inbound logistics this includes all activities that bridge the gap between the suppliers and the organization by availing products and raw materials to the organization. Efficient inbound logistics has a number of benefits including reduction, integrating suppliers to the organization so as to form participative decision making process that will ensure sustainability and more specifically environmental innovation (Bowen et al., 2001). Sustainability initiatives must be seen in all the three areas of procurement.

\subsection{Conceptual Framework}

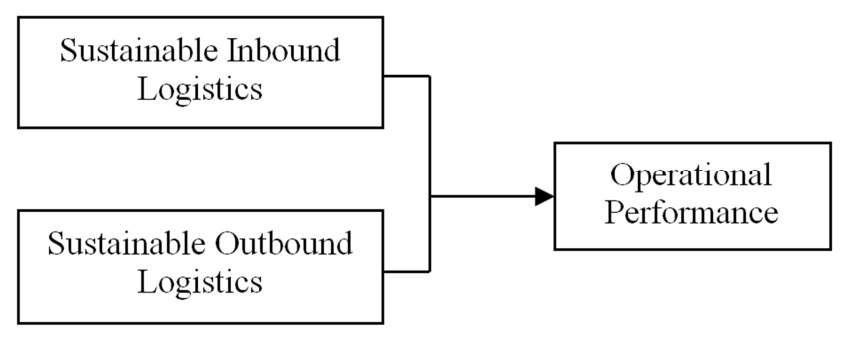

Figure 1. Conceptual Framework.

\section{Methodology}

This study adopted descriptive study design to establish the influence of sustainable logistics on operational performance. It was a survey and primary research data was collected from the respondents. The research was cross sectional as data was collected within limited time period. Because of the qualitative nature of the research data, five points; 1-Strongly disagree; 2 - Disagree; 3 - Indifferent; 4 - Agree; 5 - Strongly agree; was used to gather data on every research indicators. The target population for the study was the employees in procurement, finance and marketing departments of timber processing companies in Nakuru County. Since Comply Company was used as a case, employees in Comply Company constituted the target population, Because of the small number; all employees in procurement, finance and marketing departments of Comply Company were involved in the study. In this study, data were collected through structured questionnaires. The questionnaires were sectionalized to collect data on inbound sustainable logistics and outbound sustainable logistics and operational performance. Each section had research items to capture the needed data on the research variables. Collected data was analyzed through SPSS and presented through tables. 


\section{Findings, Conclusions \& Recommendations}

\subsection{Findings}

The study determined the influence of sustainable logistics on operational performance. The findings were as presented in this section.

Table 3. Model Summary.

\begin{tabular}{lllll}
\hline Model & R & \multicolumn{4}{l}{ R Square } & Adjusted R Square & Std. Error of the Estimate \\
\hline 1 & $.582^{\mathrm{a}}$ & .339 & .301 & .947 \\
a. & Predictors: & (Constant), Sustainable & inbound logistics, Sustainable \\
outbound logistics & & & \\
\hline
\end{tabular}

From table 3, R-square measures the explanatory power of sustainable inbound logistics and sustainable outbound logistics on operational performance. $\mathrm{R}$-square $=0.339$ from table 3 implies that sustainable inbound logistics and sustainable outbound logistics explain up to $33.9 \%$ the changes in operational performance in timber processing firms in Nakuru County.

Table 4. ANOVA Table.

\begin{tabular}{llllll}
\hline Model & Sum of Squares & Df & Mean Square & F & Sig. \\
\hline \multicolumn{1}{c}{ Regression } & 16.102 & 2 & 8.051 & 8.975 & $.001^{\text {a }}$ \\
1 Residual & 31.398 & 35 & .897 & & \\
Total & 47.500 & 37 & & & \\
a. Predictors: (Constant), Sustainable & inbound logistics, Sustainable \\
outbound logistics & & & & \\
b. Dependent Variable: Operational performance &
\end{tabular}

ANOVA test was used to test the significance of the influence of sustainable inbound logistics and sustainable outbound logistics on operational performance. Significance value of 0.001 from table 4 which is less than 0.05 implies that the overall influence of sustainable inbound logistics and sustainable outbound logistics on operational performance is statistically significant.

Table 5. Table of Coefficients.

\begin{tabular}{|c|c|c|c|c|c|}
\hline \multirow[t]{2}{*}{ Model } & \multicolumn{2}{|c|}{$\begin{array}{l}\text { Unstandardized } \\
\text { Coefficients }\end{array}$} & \multirow{2}{*}{$\begin{array}{l}\text { Standardized } \\
\text { Coefficients } \\
\text { Beta } \\
\end{array}$} & \multirow[t]{2}{*}{$\mathbf{t}$} & \multirow{2}{*}{$\begin{array}{l}\text { Sig. } \\
-(p)\end{array}$} \\
\hline & B & Std. Error & & & \\
\hline (Constant) & 7.184 & .939 & & 7.647 & .000 \\
\hline $\begin{array}{l}\text { Sustainable } \\
\text { inbound logistics, }\end{array}$ & .277 & .146 & .272 & 1.895 & .046 \\
\hline $\begin{array}{l}\text { Sustainable } \\
\text { outbound } \\
\text { logistics }\end{array}$ & .675 & .162 & .601 & 4.178 & .000 \\
\hline \multicolumn{6}{|c|}{$\begin{array}{l}\text { logistics } \\
\text { a. Dependent Variable: Operational Performance }\end{array}$} \\
\hline
\end{tabular}

Table 5 above presents the t-values that measure the influence of sustainable inbound logistics and sustainable outbound logistics on operational performance individually. The values; $\mathrm{t}=7.647 ; \mathrm{p}=0.000(<0.05)$ and $\mathrm{t}=1.895 ; \mathrm{p}=0.046$ (0.05) imply sustainable inbound logistics and sustainable outbound logistics individually have significant influence on operational performance.

\subsection{Conclusions}

From research findings, the following conclusions were made; sustainable inbound logistics is a strong determinant of operational performance. Sustainable inbound logistics is instrumental in reduction of costs and wastages that come from outside the organization through inputs used in production and normal organizational operations. Similarly, sustainable outbound logistics is a significant determinant of operational performance. Sustainability in materials and products movement to the market translated in economical distribution that enhances operational performance.

\subsection{Recommendations}

The study recommends that manufacturing and processing organizations should consider sustainable logistics activities in their operations if they are to achieve improved operational performance. The study further suggests that study be conducted to explore on sustainable logistics activities that would be used to achieve operations improvement in service industry.

\section{References}

[1] Al-Odeh, M \& Smallhood, J. (2012). Sustainable Supply Chain Management: Literature Review, Trends, and Framework. International Journal of Computational Engineering \& Management. 15 (1) 85-90.

[2] Chandrakar, R., \& Kumar, R. (2012). Overview of Green Supply Chain Management: Operation and Environmental Impact at Different Stages of the Supply Chain. International Journal of Engineering and Advanced Technology 1(3)1-6.

[3] Chien, M. K. \& Shih, L. H. (2007). An empirical study of the implementation of green supply chain management practices in the electrical and electronic industry and their relation to organizational performances. Int. J. Environ. Sci. Tech., 4 (3) 383-394.

[4] Green, K. W., Pamela, Z., Meacham J. \& Bhadauria, S. V. (2012). Green Supply Chain Management Practices: Impact on Performance. Supply Chain Management: An International Journal, 17 (3) 290-305.

[5] Kafa, N., Hani, Y. \& E. Mhamedi, A. (2013). Sustainability Performance Measurement for Green Supply Chain Management. University of Paris.

[6] Laosirihongthong, T., Adebanjo, D. \& Tan, K.C. (2013). Green supply chain management practices and performance. Industrial Management \& Data Systems 113(8)1088-1109.

[7] Mugenda, M. O. and Mugenda, G. A. (1999). Research Methods: Quantitative and Qualitative Approaches. Nairobi: Central Graphics Services.

[8] Ninlawan, C., Seksan P., Tossapol K., \& Pilada W. (2010). The Implementation of Green Supply Chain Management Practices in Electronics Industry. Proceedings of the International Multi Conference of Engineers and Computer Scientists, 17-19 March 2010 Hong Kong. 
[9] Olaf S. (2013). Reverse Logistics. Retrieved from https://www.ashgate.com/pdf/SamplePages/ghsupplych 2.pdf\#page $=1 \&$ zoom $=$ auto, $0,-22$ on $5^{\text {th }}$ August 2014 .

[10] Nylund S. (2012). Reverse Logistics and Green Logistics. A comparison between Wärtsilä and IKEA. International Business.

[11] Rha, S. J. (2010). The Impact of Green Supply Chain Practices on Supply Chain Performance. Dissertations and Theses from the College of Business Administration, University of Nebraska, 7 (20) 12.

[12] Rodrigue, P. R., Slack, B. \& Comtois, C. (2001). Green Logistics (The Paradoxes of). The Handbook of Logistics and Supply-Chain Management.

[13] Teuteberg, F. \& D. Wittstruck (2010). A Systematic Review of Sustainable Supply Chain Management Research. What is there and what is missing? Betriebliches Umweltund Nachhaltigkeits management, 1001-1015.
[14] Toke, L. K., Gupta, R. C. and Dandekar, M. (2012). An empirical study of green supply chain management in Indian perspective. Int. Journal of Applied Sciences and Engineering Research 1 (2) 372-383.

[15] Zhang, J. \& Zheng, L. (2010) Research on the Building of Green Logistics System and the Development Strategy in Jilin Province. International Conference, Logistics engineering and management, 8-10 October (2010) American Society of Civil Engineers, Chengdu, China.

[16] Zhou, F. (2009). Study on the Implementation of Green Supply Chain Management in Textile Enterprises. Journal of Sustainable Development, 2 (1) 75-78. 